Shanan HE, Zuoshuang ZHANG, Yin GU, Bing XIA, Ruizhi CHU and Hong YU

Phytohortology 
This book was originally published by Science Press, (C) Science Press, 2016.

Supported by the National Fund for Academic Publication in Science and Technology and China Biodiversity Conservation and Green Development Foundation.

\section{Shanan $\mathrm{HE}^{1}$}

Zuoshuang ZHANG ${ }^{2}$

Yin GU ${ }^{1}$

Bing XIA ${ }^{1}$

Ruizhi $\mathrm{CHU}^{1}$

Hong $\mathrm{YU}^{1}$

1 Institute of Botany, Jiangsu Province \& Chinese Academy of Sciences

2 Beijing Botanical Garden

Responsible Editors: Jing WANG and Haiguang WANG

Printed in France

EDP Sciences - ISBN(print): 978-2-7598-2530-1 - ISBN(ebook): 978-2-7598-2531-8

All rights relative to translation, adaptation and reproduction by any means whatsoever are reserved, worldwide. In accordance with the terms of paragraphs 2 and 3 of Article 41 of the French Act dated March 11, 1957, "copies or reproductions reserved strictly for private use and not intended for collective use" and, on the other hand, analyses and short quotations for example or illustrative purposes, are allowed. Otherwise, "any representation or reproduction - whether in full or in part - without the consent of the author or of his successors or assigns, is unlawful" (Article 40, paragraph 1). Any representation or reproduction, by any means whatsoever, will therefore be deemed an infringement of copyright punishable under Articles 425 and following of the French Penal Code.

The printed edition is not for sale in mainland China. Customers in mainland China please order the print book from Science Press. ISBN of the China edition: Science Press ISBN: 978-7-03-050961-1 
The Scientific Term

\section{PHYTOHORTOLOGY}

Suggested by Academician and Prof. WU Zhengyi

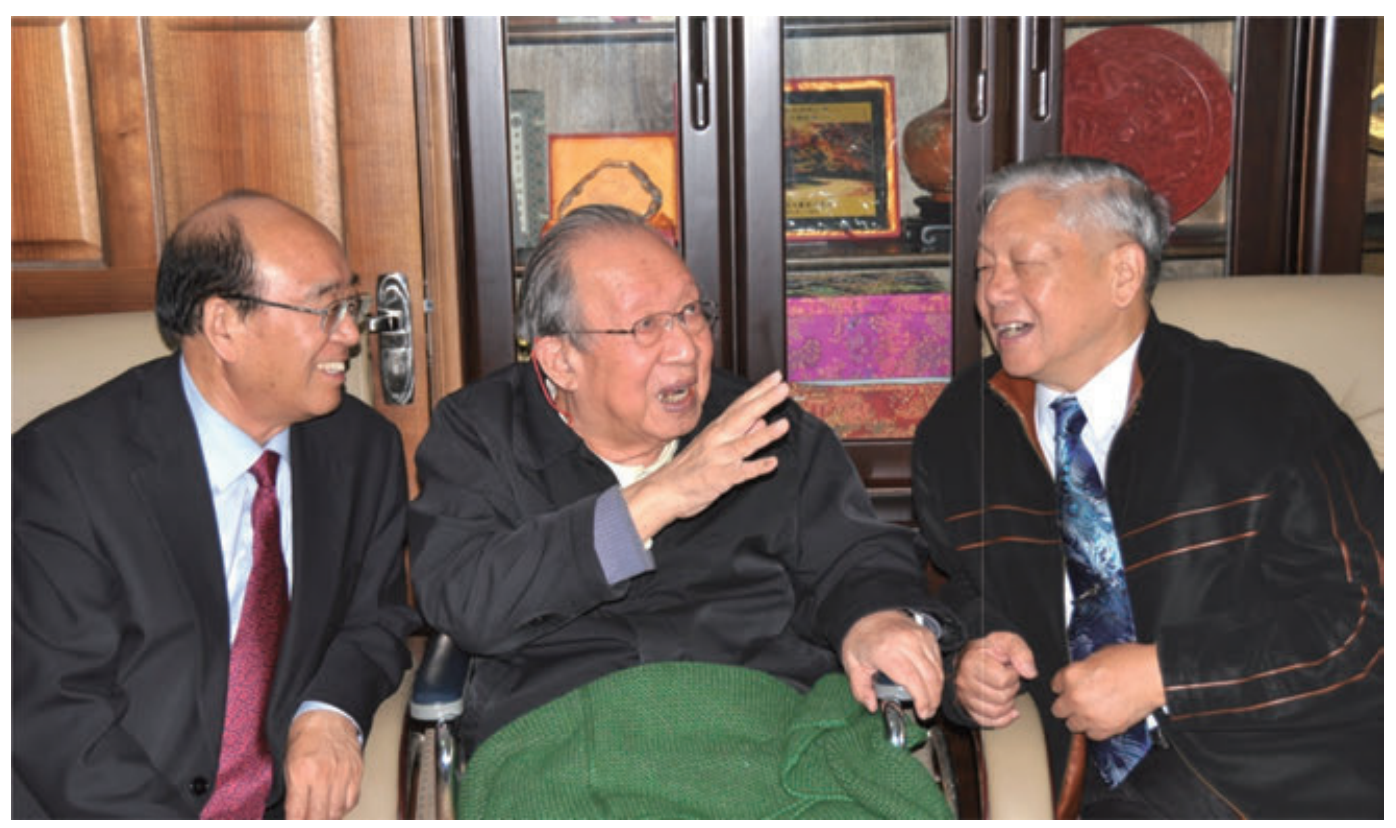

Discussing about botanical garden with Prof. WU Zhengyi in Kunming in 2008.

Left: ZHANG Zuoshuang. Central:WU Zhengyi. Right: HE Shanan 


\section{千秋》世植物園}

赠中心植物园

$$
\begin{aligned}
& \text { 李政道 } \\
& \text { 二八四京十月 }
\end{aligned}
$$

\section{BOTANICAL GARDEN, Benefiting Mankind Forever}

With Compliments to Nanjing Botanical Garden Mem. Sun Yat-Sen Tsung-Dao LEE October, 2004

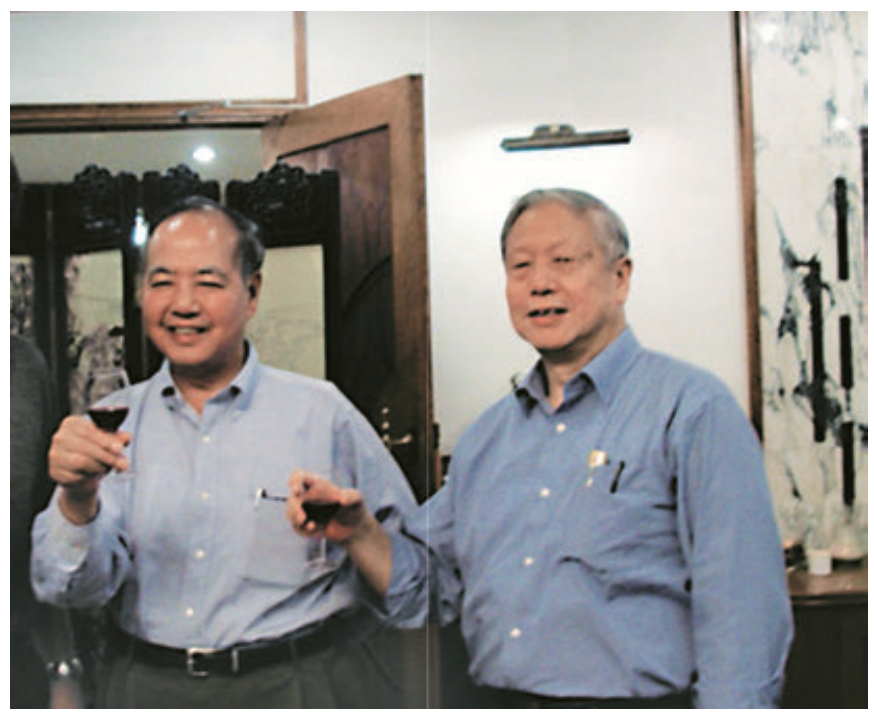

Meeting with Academician and Prof. Tsung-Dao LEE in Oct. 2004 in Suzhou City, China 